\title{
[Bionotes]
}

Zongyi Deng is an associate professor at Nanyang Technological University, 1 Nanyang Walk, Singapore 637616; e-mail: zongyi.deng@ nie.edu.sg A former associate professor at the University of Hong Kong (HKU), he is currently an honorary research associate with Wah Ching Centre of Research on Education in China, HKU. His interest areas include curriculum making, curriculum content or subject matter, educational policy, Chinese education and science education. He has published in The Sage Handbook of Curriculum and Instruction, Curriculum Inquiry, and JCS. 


\section{Confucianism, modernization and Chinese pedagogy: an introduction}

Modernization has resulted in a remarkable homogeneity in curriculum structures and pedagogic practices around the world. Individual countries with diverse historical and cultural traditions have developed very similar curriculum structures according to a universal (Western) model of schooling (McEneaney and Meyer 2000, Meyer et al. 1992). Pedagogic practices across the globe have been dominated by the 'industrial-consumer' model, in which schooling is driven by the needs of nation-states to prepare workers for the global economy, with a grade-based curriculum consisting of modern subjects like mathematics, sciences and languages (Spring 2006; see also Cheng 2011). Teaching becomes the process of delivering a body of pre-specified information, knowledge and skills controlled by a system of assessment and examination. This model has prevailed over the 'classical' educational traditions of Confucian, Buddhist, Hindu, Christian, and Islamic cultures that are concerned primarily with ethical and moral education through the reading and discussion of classic texts (Spring 2006). ${ }^{1}$ It has also triumphed over the liberal education tradition in the West centred on cultivating students' general powers of the mind through initiating them into various ways of knowing embedded in academic disciplines (see Lomas 1997, Roosevelt 2006).

Nevertheless, 'modernization' of education is by no means a progressive, linear, unproblematic process. In a non-Western country, it is inextricably associated with confrontations and competitions between Western educational thought and indigenous educational tradition. Both Western thinking and indigenous tradition have to undergo a process

\footnotetext{
${ }^{1}$ In addition, Spring (2006) argued that the 'industrial-consumer' model has triumphed over the 'progressive' tradition which is concerned with empowering students to reconstruct the society.
} 
of modification, adaptation, and transformation in a particular socio-cultural context, creating hybrid kinds of pedagogy. How was an indigenous cultural heritage transformed as it interacted with Western culture? How might the prevailing pedagogic discourse and practice be characterized as a result of the transformation? How might the authentic meaning of pedagogy inherent in a cultural heritage be re-covered? What should constitute an indigenous educational tradition? What is the role of the tradition's classics, and how should the classics be studied in today's school? How could a tradition be reconstructed in a way that enables people to confront issues and challenges created by modernization and globalization? These are important questions facing every nation in the $21^{\text {st }}$ century. To tackle these questions, it is necessary to examine the transformations of pedagogy (including both practice and its underpinning discourse) in relation to modernization of education.

China is a unique, sophisticated and fascinating case for studying complex issues concerning the transformation of pedagogy in relation to the interactions between Western educational thinking and indigenous cultural heritage over the course of modernization. As the cornerstone of Chinese traditional culture, Confucianism² has influenced and shaped Chinese educational thought and practice since 200 BCE. The ancient Chinese education system (太学 $\underline{\text { Taixue) }}$ was established to train civil servants by way of the Confucian classics ${ }^{3}$ and Chinese literature in $124 \mathrm{BCE}$, when Confucianism was elevated to the national educational doctrine. In

\footnotetext{
${ }^{2}$ Confucianism was initially a complete ideological system created by Confucius (551--479 BCE). It had evolved and transformed over the history. In the Sung dynasty (979--1279) a new form of Confucianism, neo-Confucianism, was developed, which was a creative reinterpretation of the traditional Confucian core to address the socio-economic problems of the day and the challenges posed by Buddhism and Taoism (Lee 2000). New Confucianism was another version of Confucian philosophy formed through a creative interpretation of past Confucian heritages with the aid of Western and non-Confucian ideas, as a response to Western modernity (Tan 2008).

${ }^{3}$ The Confucian classics include Book of Poetry, Book of History, Book of Change, Book of Ri, and $\underline{\mathrm{Spring}}$ and Autumn Annals.
} 


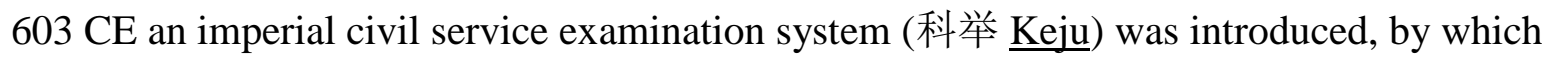
talented people were selected for positions in civil service based on their examination results in the tests of Confucian classics, Chinese literature, and so forth (Lee 2000).

The doctrinal status of Confucianism in Chinese education was only challenged when China opened its door to the outside world and underwent the process of modernization. At the risk of omission and oversimplification, we present a brief historical sketch of the four eras of China's modernization of education (also see Wu 2011), in the hope that this will provide a context for the issues to be discussed in this symposium.

- The late Qing Dynasty (1840--1911). The humiliating defeats by Western and Japanese imperial powers undermined public confidence in the Dynasty. Reformminded scholars and officials realized the need to reform the education system through borrowing advanced ideas from the West and adapting Confucianism to Western modernity. This sparked debates between reformists and traditionalists over the questions of 'Western cultural values' versus 'essential Chinese values', 'Western utilitarianism' versus 'Confucian ethics', and 'Christianity' versus 'Confucianism'. The adopted strategy was to select certain Western ideas and models and preserve essential Confucian ideas and values (Wu 2009). The turn of the century saw the abolition of the over 1,300 years old imperial civil service examination system, and the introduction of a modern western school system (adopted from Japan) (Ding 2001).

- The Republican Era (1912--1949). Confucianism was challenged and condemned by Chinese intellectuals during the New Culture Movement (1915--1919) and the May 
4th Movement (1919) that called for the creation of a new Chinese culture based on Western standards, especially democracy and science. The classical Chinese language (文言文 wenyanwen) was replaced by written vernacular language (白话 Baihua). Reform movements were carried out to promote democratization of education across China, which were grounded in Chinese intellectuals' interpretation and adaptation of Western theories to China's socio-cultural situations (Ding 2001). Likewise, Confucianism underwent a process of modernization in response to the challenges of modernity, as Chinese intellectuals interpreted or reinterpreted and transformed the philosophy of past Confucian thinkers in the light of Western and non-Confucian ideas (Tan 2008). However, during the Sino-Japanese war (1932 and then 1937-1945), attempts were made to restore Confucianism as a means to counter the influence of Western liberal and democratic theory and to educate loyal and obedient citizens (Yuan 2001).

- Mao's Era (1949--1976). Modernization took the form of Soviet and Maoist socialism after the establishment of new China. Isolated by the Western capitalist countries, headed by the US, China began to imitate the Soviet model of education and borrow its educational theories and practices. Political campaigns were carried out to purge Western influence from education. However, after the Sino-Soviet split, all Soviet educational theories were criticized. The Cultural Revolution (1966--1977) launched by Mao Zedong brought a catastrophe to China's education. The normal functions of schools were destroyed. Political campaigns were launched to attack the 'Four Olds' (old ideas, old culture, old customs, and old habits) and, later on, Confucianism in particular. This 10-year period 'not only eradicated residual Western-style education 
and the earlier emulated Soviet Union education model, but also wiped out any trace of Confucian education' (Yang and Frick 2009: 31).

- $\quad$ Reform and opening up (1977--1999). Modernization in the form of Westernization resumed and gradually gained momentum after China re-opened itself to the World. A huge quantity of Western educational theories and models had found their way into China. Following the call of Deng Xiaoping - that 'education should face modernization, the world and future'-China initiated reforms to modernize its education. When planning reforms, educational theories were selected mostly from developed countries such as the US, the UK, Canada and Japan, and were adapted to the special context of China (Ding 2001). On the other hand, Confucianism enjoyed a robust rejuvenation, as indicated in 'culture craze' (文化热 wenhuare) and 'national learning craze' (国学热 guoxuere), as 'an indispensable cultural force that ushered China into the twenty-first century' (Hon 2009: 530, Makeham 2008). ${ }^{4}$

This brief historical sketch shows that modernization of education in China is characterized by a one-and-half century old, and on-going, contestation between Western modernity and the Chinese (Confucian) tradition. During the process Western theories and values were selected, interpreted and adapted to the situation and context of China; they were inevitably transformed by Chinese traditional mode of educational thinking (Ding 2001, Wu 2009). Likewise, the Confucian tradition was reinterpreted, transformed and reinvented when interacting with Western modern culture (Tan 2008). The prevailing pedagogy in Chinese

\footnotetext{
${ }^{4}$ However, Makeham (2008) argued that the Confucian revival was primarily an intellectual movement in which academia employed Neo-Confucian philosophy of the 10th to 17th centuries to address contemporary issues facing China.
} 
classrooms reflects a mixture embodying both Western and Chinese (Confucian) characteristics (Cheng 2011; see also Biggs and Waktins 1996, 2001).

In the $21^{\text {st }}$ century, the contestation takes on a new meaning and significance as China rises to become the global economic power house. China continues to 'import' varieties of educational theories from the West. However, the legitimacy and suitability of Western theory are questioned by Chinese educators on the grounds that China has its own distinct culture and tradition, with unique issues and problems. They call for the development of distinctively Chinese educational theories—as a matter of national pride — through analyzing the current situations and finding depths and achievements of Chinese history and tradition (cf. Jiang 2008, Shen et al. 2010). The resurgence of Confucianism continues into the new century, accompanied by a strong interest in the rediscovery of Chinese tradition and history. It is believed that China should return to its own roots for inspiration, producing its own norms and standards (Tian and Johnston 2008, 'Nothing new' 2011, 'The debate' 2010). This is well reflected in Zongjie Wu's essay in this issue of $\underline{\mathrm{JCS}}$, to which we now turn.

The symposium consists of the essay by $\mathrm{Wu}$ and five commentaries by scholars in mainland China, Hong Kong and Singapore. In his 'Interpretation, autonomy and transformation: Chinese pedagogic discourse in a cross-cultural perspective', $\mathrm{Wu}$ (2011) attempts to recover the (authentic) Confucian pedagogic discourse through 'de-constructing' contemporary pedagogic discourse in China. The article consists in a 'critical discourse analysis' of two 'classroom' texts, a dialogue between Confucius and his student in Analects and an episode of a contemporary lesson on Chinese classics. As Wu reveals, in Confucius' pedagogy the student initiates inquiry, the teacher detects the student's 'horizon of readiness' and engages him or her in a 'heart-toheart' dialogue with the help of a classic text. Knowledge is treated as 'intuitive insight' and 
language is kept to minimum. This contrasts sharply with contemporary Chinese pedagogy where learning is a process of accumulating facts and propositions and Chinese classics is interpreted by means of linguistic categories and representations. Wu argues that contemporary Chinese pedagogic discourse is 'articulated in westernized discourses that have been normalized as China's own' (p. xxx). Invoking Heidegger's work on 'authentic language', he concludes the article by calling for finding the 'Way' back to the authentic Chinese language in order to recover the authentic Chinese pedagogic discourse.

In the first commentary, titled 'Pedagogy: east and west, then and now', Kai-ming Cheng (2011) sees Wu's paper in terms of an invitation 'to look at the treasures embedded in the Chinese culture' (p. xxx). What the paper reveals about Confucian pedagogy is consistent with contemporary understanding of human learning, and therefore, 'modern theories of learning are just a re-discovery of Confucian pedagogy' (p. xxx). However, he takes issue with Wu's assumption about the historical continuity of the Confucian heritage of pedagogy: long before China interacted with Western culture, traditional Confucian pedagogy had been fundamentally altered due to the implementation of the imperial civil service examination system. Furthermore, he questions Wu's linguistic or discourse deterministic account of Chinese contemporary pedagogy by linking the mainstream Western pedagogy (rather similar to the Chinese contemporary pedagogy) to the economic evolutions over the last two hundred years and, more specifically, to the 'industrial and manufacturing paradigm'. He points out that the prevailing pedagogy in China embodies both Western and Chinese characteristics.

The second commentary is 'Pedagogic discourse and transformation: a selected tradition' by Yongbing Liu. Liu (2011) starts with explaining the significance of Wu's essay with reference to China's current curriculum reform and the related debate over the relationship 
between the Chinese and Western pedagogic traditions. What Wu's article reveals is that contemporary Chinese pedagogic discourse has been 'hybridized' with Western discourses and values, and therefore, no clear divide exists between the Chinese and Western pedagogic traditions (p. xxx). Next he questions Wu's representation of (authentic) Confucian pedagogy by arguing that the chosen Confucius-student dialogue was a artefect produced by Confucius' disciples over 2000 years ago. Like Cheng, he points out that traditional Confucian pedagogy had evolved and transformed with the changing social environments, long before the 'invasion' of Western culture and value. Wu's main problem, according to Liu, is his failure to recognize the evolving nature of Confucian pedagogy. Furthermore, he points out the problematic dualistic distinction between 'desirable' traditional Confucian pedagogy and 'undesirable' contemporary Western pedagogy implied in Wu's paper. He observes that Wu fails to make a distinction between language and metalanguage and between discourse and language.

In the third commentary, 'The complexity of Chinese pedagogic discourse', Liang Cheng and $\mathrm{Nan} \mathrm{Xu}$ (2011) acknowledge Wu's contribution to the contemporary debate between western educational thought and Chinese educational tradition — in terms of his attempt to recover the real meaning of Confucian pedagogic discourse and to 'demystify' Chinese contemporary (Westernized) pedagogic discourse. However, they point out that Wu's analysis of the two 'classroom' texts 'strips away their historical contexts in general and education circumstances in particular' (p. xxx). As a result, Wu has overlooked the essential differences in terms of ends, content and teacher roles between traditional Confucian and contemporary pedagogies. Wu's problem, Cheng and $\mathrm{Xu}$ further contend, lies in his presupposition of a dichotomy between Chinese traditional pedagogic discourse and Western pedagogic discourse and a discontinuity between tradition and modernity. According to Cheng and $\mathrm{Xu}$, in contemporary pedagogical 
discourse 'Chinese traditional discourse is entangled with rather than replaced by Western discourse' (p. xxx). Tradition does not exist in the past but dwells in our presence. The meaning of Confucian pedagogy, therefore, 'should not [and could not] be "recovered" from the past, but should be "found" in the present' (p. xxx).

Tongdong Bai (2011) begins his 'Against democratic education' by pointing out two methodological issues involved in Wu's analysis of the two 'classroom' texts---'reverseOrientalism' and 'fundamentalism'. Like Cheng and Xu, Bai focuses the discussion on what Wu has probably overlooked with respect to the two 'classroom' texts. He argues that two texts imply two fundamentally different kinds of education which are not comparable with each other. The kind exemplified in the Confucius-disciple dialogue is 'philosophical education' for the elites and nobles that was practised by many ancient thinkers, like Confucius and Socrates. The kind reflected in the contemporary lesson is 'education of the masses' with 'democratic education' as its Western counterpart. Because of the attempt to provide 'philosophical education' to everyone, according to Bai, Western education inevitably leads to problems like a watered-down curriculum, the disrespect for classics, etc.. Bai believes that traditional Chinese education provides a solution to some of the problems inherent in Western mass (democratic) education.

In the fifth commentary, 'Why study Chinese classics and how to go about it', Sor-hoon Tan (2011) commends Wu's essay for his debunking of the popular but mistaken blaming of Confucian pedagogy for rote learning, regurgitation and memorization, and for his rediscovery of Confucian pedagogic discourse as supporting teaching that is 'open and free', facilitating 'movement toward understanding and becoming' through helping students find a right language (p. xxx). However, Tan questions Wu's attempt by pointing out that it is impossible to recover 
the authentic Confucian pedagogic discourse because one cannot return to a time 'innocent' of Western influence. Furthermore, she points out that Wu's East--West dualism 'oversimplifies and blinds us to the complexity of China history and culture and unnecessarily limits future possibilities' (p. xxx). She questions Wu's recovery of the authentic language from Analects as a language 'pointing to nameless'. As an alternative to Wu's proposal for recovering an authentic Chinese education, Tan provides a Deweyan account of making Chinese education authentic which requires, among other things, educators to inquire about 'how the Chinese see their experience being organized and reconstructed in order to add meaning to their experience and increase their ability to direct future experience' (p. xxx), and how Chinese classics can be used as 'intellectual tools to construct new visions of good life that resonate with their [Chinese people's] valuable past' (p. xxx).

The discussion around issues raised in Wu's paper will continue in future issues of JCS.

Our goal is to create a forum for discussion and dialogue within the context of modernization and globalization on the complexity of Chinese education---in light of China's fascinating history and rich cultural heritage as well as its current reforms and aspirations. We believe such discussion and dialogue is timely as Chinese education has been increasingly attracting attention all over the world.

\section{$\underline{\text { Acknowledgement }}$}

I want to express my deep gratitude to Ian Westbury who initiated this symposium and has provided immense support and guidance throughout the entire process. The symposium would 
not have been possible without his invaluable contribution. Special thanks also go to Yuzhen Xu, Benjamin Wong, and Yanping Fang who have contributed to the symposium in various ways.

\section{$\underline{\text { References }}$}

Bai. T. (2011) Against democratic education. Journal of Curriculum Studies, 43(5), xxx-xxx

Biggs, J. B. and Waktins, D. A. (1996) The Chinese learner in restrospect. In D. A. Watkins and J. B. Biggs (eds), The Chinese Learner: Cultural, Psychological and Contextual Influence (Hong Kong/Melbourne: Comparative Educational Research Centre, The University of Hong Kong/Australian Council for Educational Research), 269--285.

Biggs, J. B. and Watkins, D. A. (2001) Insights into teaching the Chinese learner. In D. A. Watkins and J. B. Biggs (eds), Teaching The Chinese Learner: Cultural, Psychological and Contextual Perspectives (Hong Kong/Melbourne: Comparative Educational Research Centre, The University of Hong Kong/Australian Council for Educational Research), 277--300.

Cheng, K. M. (2011) Pedagogy: east and west, then and now. Journal of Curriculum Studies, 43(5), $\mathrm{xxx}-\mathrm{Xxx}$. 
Cheng, L. and Xu, L. (2011) The complexity of Chinese pedagogic discourse. Journal of Curriculum Studies, 43(5), xxx-xxx.

Ding, G. (2001) Nationalization and internationalization: two turning points in China's education in the twentieth century. In G. Peterson, R. Hayhoe and Y. Lu (eds), Education, Culture, \& Identity in Twentieth-Century China (Hong Kong: The University of Hong Kong Press), 161-186.

Jiang, S. Q. (2008) An initial exploration of a system of distinctively Chinese socialist educational theory [中国特色社会主义教育理论体系初探]. Education Exploration [教育探 索], 2008 (10), 13--14.

Hon, T. K (2009) [Review of the book Lost Soul: 'Confucianism' in Contemporary Chinese Academic Discourse, by J. Makeham]. Journal of Chinese Studies, 49, 530--533.

Lee, T. H. C. (2000) Education in Traditional China: A History (Leiden, The Netherland: Brill).

Liu, Y. (2011) Pedagogic discourse and transformation: a selective tradition. Journal of Curriculum Studies, 43(5), $\mathrm{xxx}-\mathrm{xxx}$. 
Lomas, L (1997) The decline of liberal education and the emergence of a new model of education and training. Education+Training, 39(3), 111--115.

Makeham, J (2008) Lost Soul: 'Confucianism' in Contemporary Chinese Academic Discourse (Cambridge, MA: Harvard University Asia Centre).

McEneaney, E. H. and Meyer, J. W. (2000) The content of the curriculum: an institutionalist perspective. In M. T. Hallinan (ed.), Handbook of the Sociology of Education (New York: Springer), 189--211.

Meyer, J., Kamens, D. and Benavot, D. (1992) $\underline{\text { School Knowledge for the Masses: World Models }}$ and National Primary Curriculum Categories in the Twentieth Century (London: Falmer).

'Nothing new under heaven'. The Economist, 16 June, 2011.

Roosevelt, G. (2006) The triumph of the market and the decline of liberal education: implications for civic life. Teachers College Record, 108(7), 1404 --1423.

Shen, X. B., Wang, T. P, and Zhang, D (2010) A survey of genre construction in curriculum and instruction theory in China [对中国课程与教学论流派构建的审思]. Journal of Southwest University [西南大学学报], 36(1), 135--139.

Spring, J. (2006) Pedagogies of Globalization: The Rise of the Educational Security State (Mahwah, NJ: Lawrence Erlbaum) 
Tan, S. H. (2008) Modernising Confucianism and New Confucianism. In K. Louie (ed.), The Cambridge Companion to Modern Chinese Culture (Cambridge, UK: Cambridge University Press), 135--54.

Tan, S. H. (2011) Why study Chinese classics and how to go about it. Journal of Curriculum Studies, 43(5), xxx-xxx

'The debate over universal values; China'. The Economist, Oct. 22010.

Tian, J. and Johnston, C. (2008) The 2008 Olympic games: leveraging a 'best-ever' games to benefit Beijing. Asian Social Science, 4(4), 22--47.

Wu, M. (2009) The transformation of the educational semantic within a changing society: a study of the Westernization of modern Chinese education. Journal of Historical Sociology, 22(4), 528--522.

Wu. Z. (2011) Interpretation, autonomy, and transformation: Chinese pedagogic discourse in a cross-cultural perspective. Journal of Curriculum Studies, 43(5), xxx--xxx 
Yang, J. and Frick, W. (2009) Will the leadership of Chinese education follow the footsteps of American education: a brief historical and socio-political analysis. Journal of Thought, 44(3\&4), $23--48$.

Yuan, Z. (2001) The status of Confucianism in modern Chinese education, 1901--49. In G.

Peterson, R. Hayhoe and Y. Lu (eds), Education, Culture, \& Identity in Twentieth-Century China

(Hong Kong: The University of Hong Kong Press), 193--216. 